\title{
An Assessment of Nonequilibrium Dynamics in Rangelands of the Aru Basin, Northwest Tibet, China
}

\author{
Tsechoe Dorji, ${ }^{1}$ Joseph L. Fox, ${ }^{2}$ Camille Richard, ${ }^{3}$ and Kelsang Dhondup ${ }^{4}$
}

Authors are ${ }^{1}$ Lecturer, Plant Science and Technology Department, College of Agriculture and Animal Husbandry, Tibet University, College Road No. 8 , Bayi Township, Nyingchi District, Tibet Autonomous Region 860000, P. R. China; ${ }^{2}$ Senior Associate Professor, Department of Biology, Faculty of Science, University of Tromsø, N-9037 Tromsø, Norway; ${ }^{3}$ Rangeland Consultant, P.O. Box 188, Lake City, CO 81235, USA; and ${ }^{4}$ Research Associate, Tibet Academy of Agriculture and Animal Husbandry Sciences, No. 130 JinZhu XiLu, Lhasa, Tibet Autonomous Region 850002, P. R. China.

\begin{abstract}
An assessment of nonequilibrium rangeland dynamics was conducted in the Aru basin, a semiarid site located in the very dry northwest part of the Chang Tang Nature Reserve, Tibet, China. A grazing gradient approach was used to examine the effects of different livestock grazing intensities on vegetation, providing data to determine if plant-herbivore interaction has been a major structuring force of the plant community and thus to indicate what type of dynamic might apply in the study area. No significant differences were found between a highly grazed site and a lightly grazed site in vegetation cover, standing biomass, and ShannonWiener species diversity index of total, graminoid, forb, and tomtza (Oxytropis glacialis Benth. ex Bunge) functional groups, with the exception that tomtza coverage was significantly higher at the highly grazed $(1.04 \%)$ than at the lightly grazed site $(0.02 \%)$. Grazing intensity alone did not explain a significant amount of variation in the plant species data. These results indicate that a dominance of nonequilibrium dynamics appears to be the case in the basin, probably one of the least-arid sites in the northwest Chang Tang region of the Tibetan Plateau. Thus, opportunistic livestock management strategies adapted to variable vegetation production from year to year, rather than the setting of a rigid stocking rate that assumes a stable carrying capacity, is probably the most plausible approach for managing livestock and its relationship to biodiversity values in this region.
\end{abstract}

\section{Resumen}

Se llevó a cabo una evaluación de la dinámica de no-equilibrio de la llanura en la cuenca del Aru, un sitio semi árido que se encuentra en la parte noroeste de la Reserva Natural Chang Tang, Tibet, China, que es una zona muy árida. Se utilizó una aproximación basada en un gradiente de pastoreo para examinar los efectos de distintas intensidades del pastoreo sobre la vegetación, aportando datos para determinar si la interacción plantas-herbívoros ha sido una fuerza estructural principal de la comunidad vegetal, y en tal caso para indicar qué tipo de dinámica puede estar sucediendo en el área de estudio. Una prueba de " $t$ " Welch de dos muestras no mostró diferencias significativas entre un área con pastoreo intenso y otra con pastoreo leve, en términos de cobertura de la vegetación, biomasa en pie, y respecto al índice de diversidad de especies Shannon-Wiener para los grupos de gramíneas, herbáceas, y tomtza (Oxytropis glacialis) y para todos en conjunto, con la excepción de la cobertura de tomtza, que fue significativamente más alta en las zonas muy pastoreadas $(1.04 \%)$ que en las ligeramente pastoreadas $(0.02 \%)$. El análisis de correspondencias canónicas (ACC) con test de permutación de Monte Carlo también indicó que la intensidad de pastoreo por sí sola no explicó una cantidad de variación significativa de especies vegetales. Estos resultados indican que condiciones de noequilibrio dominan en la cuenca, probablemente uno de los sitios menos áridos en el noroeste de la región Chang Tang de la meseta tibetana. Por tanto, estrategias de manejo del ganado oportunistas, adaptadas a las variaciones interanuales de producción de vegetación, más que el establecimiento de cargas rígidas que asumen una capacidad de carga estable, son probablemente las más razonables para manejar el ganado en relación con la conservación de la biodiversidad en esta región.

Key Words: biodiversity, grazing gradient, rangeland assessment, rangeland ecosystem management, species diversity

\section{INTRODUCTION}

There are several rangeland dynamic theories at present, each of which relates to the extent of linkage between plant and

Research was funded in part by the Network for University Co-operation Tibet-Norway, the University of Tromsø's Faculty of Science, and its Center for Environment and Development Studies.

At the time of the research the senior author was a graduate student at the University of Tromsø, Norway, supported by the World Wildlife Fund-USA, Trace Foundation, and the Tibet-Norway Network.

Correspondence: Tsechoe Dorji, Plant Science and Technology Dept, College of Agriculture and Animal Husbandry, Tibet University, College Road No. 8, Bayi Township, Nyingchi District, Tibet Autonomous Region 860000, P. R. China. Email: tsechoedorj@yahoo.com

Manuscript received 5 February 2009; manuscript accepted 16 January 2010. herbivore production (Briske et al. 2003). The equilibrium and nonequilibrium theories have been those discussed most extensively in the rangeland ecology literature. The equilibrium theory is based on the assumption that biological interactions dominate in the process of structuring communities or regulating populations (DeAngelis and Waterhouse 1987); thus, plant interspecific competition and biomass productivity are controlled by herbivores (Behnke and Scoones 1993; Fernandez-Gimenez and Allen-Diaz 1999). In contrast, under nonequilibrium conditions, stochastic variation plays a more significant role; plant biomass primarily is controlled by abiotic factors such as temperature, precipitation, and wind (Behnke and Scoones 1993; Fernandez-Gimenez and Allen-Diaz 1999). Thus, plant-animal interactions are density-independent and 
grazing has a limited effect on long-term grassland productivity (Scoones 1995). Nevertheless, the dichotomy is not exclusive. Intensive grazing can affect dry nonequilibrium systems, and environmental variation can interact with grazing to elicit changes in vegetation (Warren 1995; Gillson and Hoffman 2007). The specific interactions of these factors in a site are critical to understanding these dynamics.

The applicability of these theories in real biological ecosystems has generated a great deal of controversy (Shinneman and Baker 1997; Illius and O'Connor 1999). It is apparent that spatial and temporal scales are important components when the applicability of such models is concerned (Connell and Sousa 1983; DeAngelis and Waterhouse 1987; Illius and O'Connor 1999). A number of models suggest that the stable equilibrium state is a property of large spatial scales (DeAngelis and Waterhouse 1987); however, problems remain regarding delimitation and selection of the appropriate spatial and temporal scales for community analysis (Rahel et al. 1984). Some ecologists have attempted to quantify and sharpen predictions about where nonequilibrium dynamics are likely to occur, based on overall precipitation and its interannual coefficient of variation (CV). Ellis (1995), for example, argues that arid environments with mean annual rainfall less than $250 \mathrm{~mm}$ and an interannual CV greater than 33\% generally have nonequilibrium characteristics.

The grazing gradient approach for assessing rangeland condition is well-established as a useful technique for assessing rangeland dynamics over various spatial and temporal scales (Behnke and Scoones 1993; Pickup and Bastin 1997; Pickup et al. 1998; Fernandez-Gimenez and Allen-Diaz 1999). Because livestock grazing intensity generally decreases with distance from herding camps and livestock watering sites (Valentine 1945), comparison of vegetation attributes (e.g., cover, composition, productivity, and species richness) in sites with high and low grazing intensity can elucidate the extent to which grazing affects the system (Fernandez-Gimenez and Allen-Diaz 1999).

However, grazing pressure is not necessarily the only causal factor for variation in species abundance and richness along a grazing gradient, even in a presumed homogeneous condition. In nature, even slight differences in soil chemical composition and topographic features can result in different vegetation features and community structure (Heikkinen et al. 1998; Körner 2003). Soil chemical composition can show considerable spatial heterogeneity, even at small scales (Jackson and Caldwell 1993), whereas the availability nutrients such as nitrogen, phosphorus, potassium, and soil organic matter can be important in determining vegetation production, species richness, and plant community composition (Theodose and Bowman 1997). In addition, because topographic features such as aspect and slope can affect plant growth and reproduction (Rorison et al. 1986), measurement of soil and topographic parameters can be used to characterize the sites being selected for study.

In this study, we assessed the nonequilibrium dynamics of rangelands in the Aru basin, a semiarid site in the very dry northwest Chang Tang (Fig. 1), to validate the justification for ongoing rangeland policies. These policies promote rangeland improvements such as setting stocking rates, reseeding, fencing, and cultivating forage crops, and are being implemented to "restore" vegetation in areas that are perceived as "degraded" rangeland based on equilibrium theory. We hypothesized that the semiarid Aru basin, as well as the drier rangelands of northwest Chang Tang are controlled by nonequilibrium dynamics. We further predicted that vegetation cover, productivity, and species richness would not significantly differ between historically heavily and lightly grazed sites.

\section{METHODOLOGY}

\section{Study Area}

The study area is in the western Aru basin, a $2300-\mathrm{km}^{2}$ enclosed catchment situated at ca. $5000 \mathrm{~m}$ elevation and adjacent to mountains rising over $6000 \mathrm{~m}$ located in the northwest part of the Chang Tang (Fig. 1). The average annual temperature and precipitation in this part of the Chang Tang is less than $0^{\circ} \mathrm{C}$ and $100 \mathrm{~mm}$, respectively, according to climate maps from Chinese Academy of Science (http://ib.igsnrr.ac.cn/ gdlisweb/search.aspx? \& $\mathrm{db}=$ local), and interannual $\mathrm{CV}$ is greater than $33 \%$. The basin, adjacent to high mountains that result in increased precipitation, is an important habitat for Tibetan antelope (Pantholops hodgsonii), with a summer population of about 1500 males (females migrate north for calving during this season) and sometimes well over 10000 individuals of both sexes in the autumn and winter (Fox et al. 2004). Approximately 350 Tibetan gazelle (Procapra picticaudata), 150 kiang (Equus kiang), 350 blue sheep (Pseudois nayaur), and 200 wild yaks (Bos grunniens) also are present in the basin (Fox et al. 2004).

The basin supports year-round grazing by herders from two counties, Gertse and Rutok, with about 8000 domestic livestock including sheep, goats, yaks, and horses in winter and about 15000 in summer (Fox et al. 2004). An approximately $200-\mathrm{km}^{2}$ portion of the basin, encompassing its western lowlands and lower hills, is used as a summer grazing area due to its good pasture at this season and the higher risk of snow here (compared with elsewhere in the basin) during other seasons. One of the reasons for selecting the summer grazing area for study was its relatively moist nature (in testing the nonequilibrium dynamic, because the winter pastures are even drier and should thus be even "more" nonequilibrium) and the higher numbers of livestock using this area than wintering areas in the basin. A further reason for selecting the Aru basin for study was because it is one of the most important habitats for some distinctive and threatened wildlife species (Schaller 1998) as well as a rapidly developing site for animal husbandry (Fox et al. 2008). Thus, it is a crucial area related to the interaction between wildlife conservation and animal husbandry development within the Chang Tang Nature Reserve.

\section{Study Design}

In this study, grazing gradients radiating away from the main Gertse herders summer campsites were used to examine the effects of livestock grazing pressure on vegetation to determine whether the plant-herbivore interaction is an important influence in structuring the rangeland ecosystem in the relatively moist western portion of the Aru basin. There were two campsites in the Gertse part of western Aru basin, one consisting of two families and the other of three families, but 


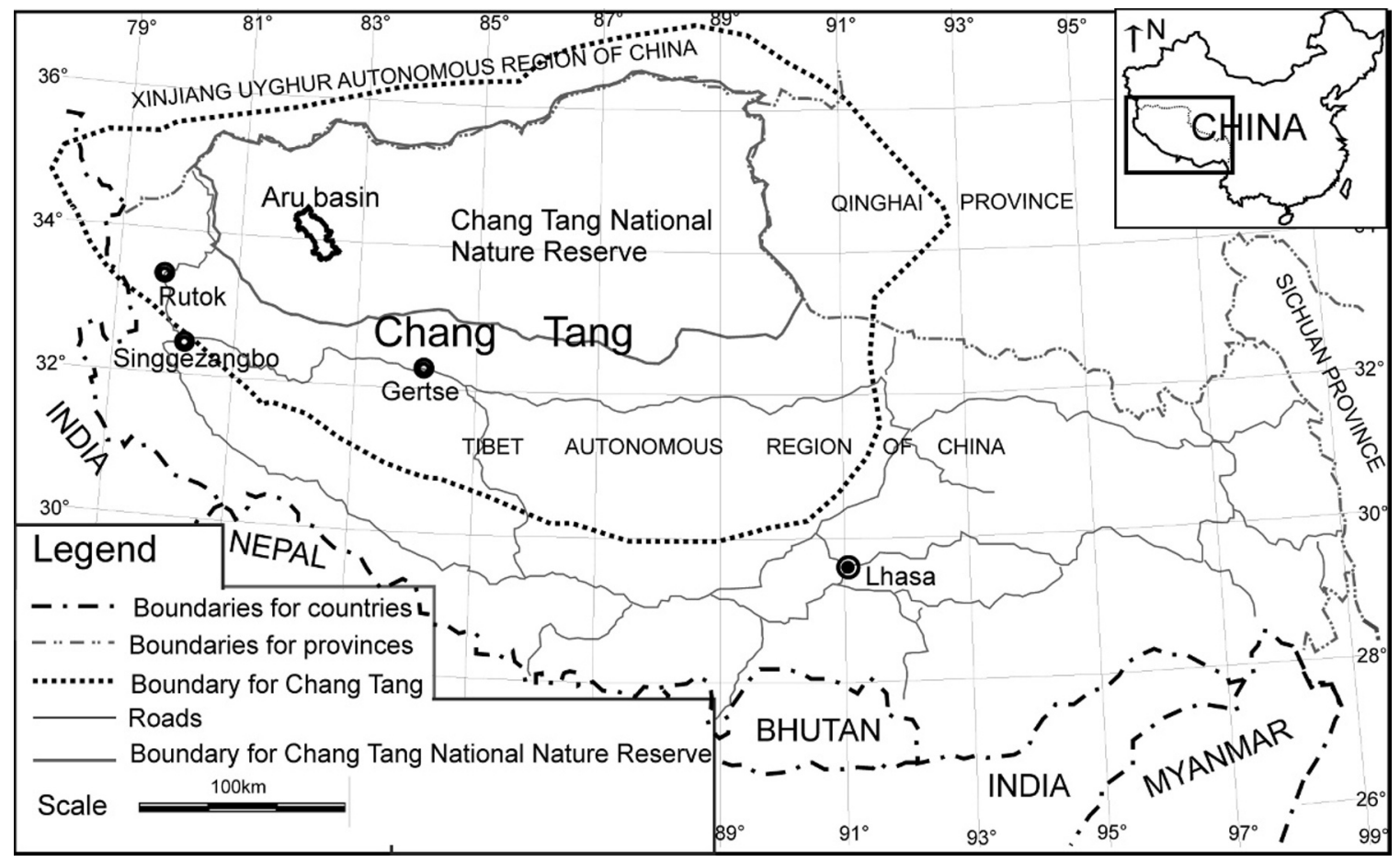

Figure 1. Map shows the general location of the Aru basin, the Chang Tang National Nature Reserve. The Chang Tang region is defined based on the description by Liu (1999) and illustrated on http//www3.utsidan.se/corax-e/2003/maps.htm\#Maps, outlined on a map of the Tibet Autonomous Region from the Chinese Academy of Science.

both have approximately the same livestock populations. However, livestock population can vary year to year according to interviews with local herders. Areas were delineated as highly and lightly grazed areas based on observations of local herding patterns, seasonal wild ungulate distributional patterns, and interviews with local people regarding these factors. The highly grazed area was defined as being within an approximately $3-\mathrm{km}$ radius of primary camps/water sources. Lightly grazed areas were those at least $5 \mathrm{~km}$ from such camp sites, where little or no livestock and wild ungulate grazing occurs, but that are within the same presumed vegetation zone. The highly grazed area selected is a traditional livestock summer grazing area and it is also one of the major autumn-winter areas of concentration for Tibetan antelope, thus enhancing its status as a relatively heavily grazed site. The lightly grazed area is neither an important livestock grazing area nor a wild ungulate winter concentration area. Although there is clearly some amount of grazing within the lightly grazed area (primarily male chirus and gazelles in summer), it can be considered negligible due to their small population sizes and scattered distribution. Additionally, small grazing animals such as pikas were not abundant in the site selected.

Ten transects of 200-m length each were randomly placed in each of the highly (10 transects total from both of the campsites with random allocation) and lightly grazed areas. For vegetation measurements, we placed 20 quadrats, each $0.25 \mathrm{~m}^{2}$, along each transect with $10-\mathrm{m}$ intervals between quadrats. Locations and elevations for transects were derived using Global Positioning System (GPS) receivers. Aspects and slope angles were derived from a digital elevation model using a geographic information system technique. For the purpose of numerical analysis, aspects were categorized into eight units (east, southeast, south, southwest, west, northwest, north, and northeast) and assigned a number from 1 to 8 according to the degree in which the different aspects were exposed to the sun.

\section{Data Collection}

Foliar cover of plant species and its richness were estimated by using the pin-point intercept method (Fisser and Van Dyne 1966), evenly distributing 50 pins in the quadrat. The number of plant species encountered along each transect was recorded, thus providing an estimate of species richness. All the vegetation measurements were taken from 15 August to 6 September 2005, at the end of the vegetation growing season.

Table 1. Welch's Two-Sample $t$ test results showing effects of the summer 2005 livestock grazing on vegetation coverage, standing crop biomass, and Shannon-Wiener species diversity index for total species, graminoids, forbs, and tomtza in heavily grazed sites of the Aru basin.

\begin{tabular}{lrll}
\hline \multicolumn{1}{c}{ Variable } & \multicolumn{1}{c}{$t$} & \multicolumn{1}{c}{$P$} & \multicolumn{1}{c}{$\mathrm{df}$} \\
\hline Total coverage & 0.6323 & 0.5596 & 4.26 \\
Graminoids & 0.6624 & 0.5548 & 3.019 \\
Forbs & -1.1336 & 0.3533 & 2.516 \\
Tomtza & 1.3954 & 0.2803 & 2.346 \\
Total standing crop & 0.5818 & 0.6031 & 2.882 \\
Graminoids & 1.4945 & 0.1666 & 9.777 \\
Forbs & -0.9816 & 0.3978 & 3.038 \\
Tomtza & 1.7026 & 0.2190 & 2.205 \\
Shannon index for total & -0.4811 & 0.669 & 2.525 \\
For graminoids & 0.3244 & 0.7517 & 10.969 \\
For forbs & -0.7518 & 0.5128 & 2.674 \\
\hline
\end{tabular}




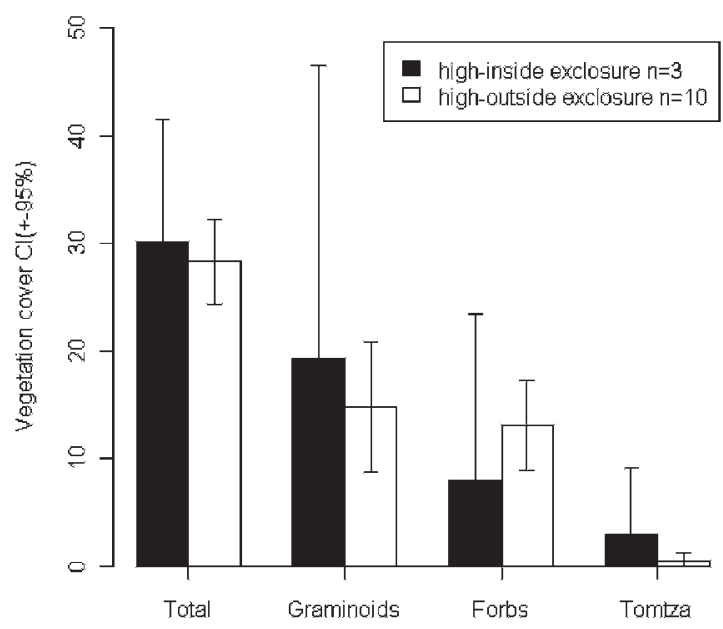

(a)

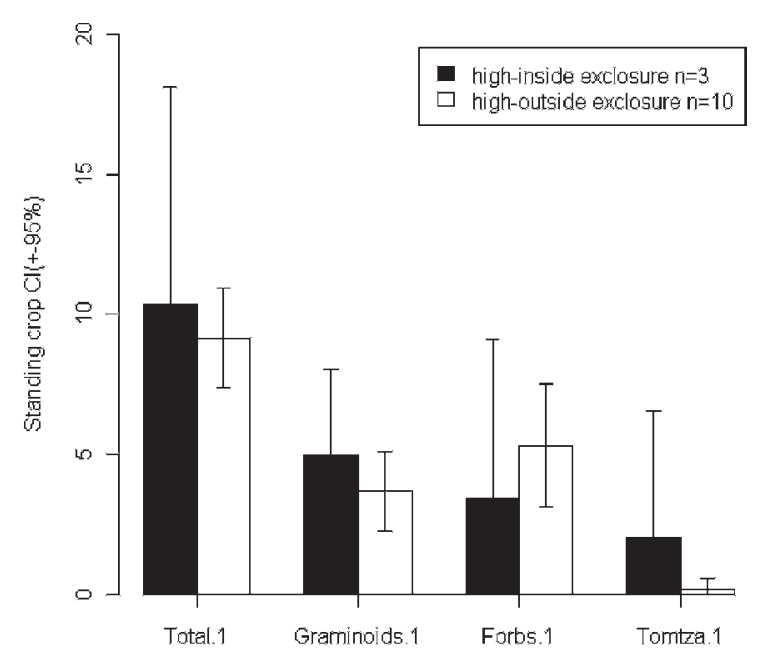

(b)

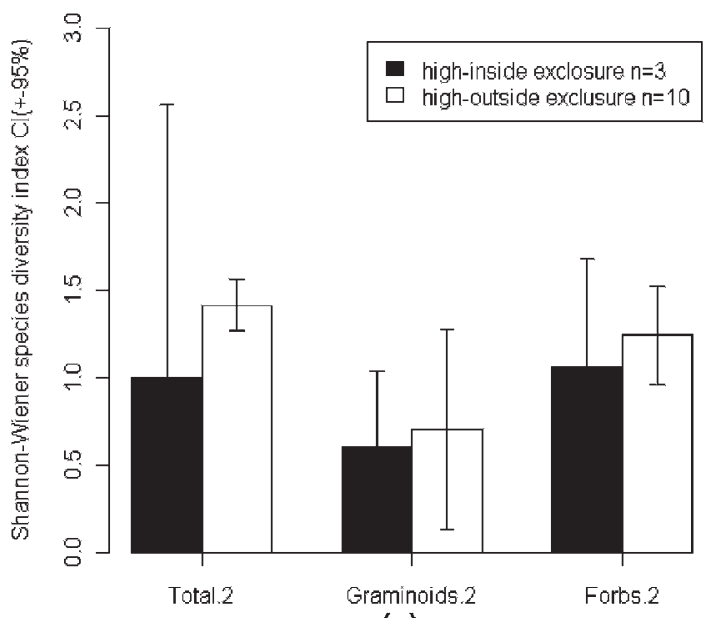

(c)

Figure 2. Bar plots with $95 \%$ confidence intervals $(\mathrm{Cl})$ illustrating differences in a, vegetation cover ( $\%)$; $\mathbf{b}$, standing biomass $\left(\mathrm{g} \cdot 0.25 \mathrm{~m}^{-2}\right)$; and $\mathbf{c}$, Shannon-Wiener species diversity index for total species, graminoids, forbs, and tomtza inside and outside of exclosures in heavily grazed sites in the western Aru basin.

Because plant life forms respond differently to various environmental perturbations and changes (Semenova and van der Maarel 2000), the vegetation data were separated into two life form-related functional groups, graminoids and forbs (the latter including dwarf shrubs), and one known poisonous forb, Oxytropis glacialis, locally known as "tomtza," and separated due to its known toxicity (Tan et al. 2002). Vegetation coverage data for each transect consisted of the mean percentage cover calculated from each of the 20 quadrats, for each functional group and the selected toxic species. ShannonWiener species diversity index was calculated as

$$
H^{\prime}=-\sum_{i=1}^{S} p_{i} \ln p_{i}-[(S-1) / 2 N]
$$

where $S$ is the number of species, also called species richness; $N$ is the number of all individuals; and $p_{i}$ is the relative abundance of each species (the mean number of pins hit by each species calculated from each of the 20 quadrats along each transect). Species richness was the number of species present along each transect for the functional groups.

Standing crop biomass was estimated by clipping all plants (separated as graminoids, forbs, and tomtza) from four of the 20 quadrats per transect. At the highly grazed area, in addition to the measurements in grazed vegetation, three $100-\mathrm{m}^{2}$ fenced exclosures were randomly placed to measure ungrazed standing crop biomass, and used to estimate if the actual livestock grazing during summer 2005 affected plant biomass production. The exclosures were set up on 20 June 2005 when plants were starting to grow and before livestock had been moved to the summer camps. Within each exclosure, 50 quadrats were randomly placed to estimate plant coverage and species richness, of which 20 were clipped. All clipped plants were air dried and weighed using a standard balance. Measurements from all the quadrats in each exclosure were averaged to derive means of each 
Table 2. Results from Welch's Two-Sample $t$ tests comparing effect of different grazing intensities (heavy, light) on vegetation coverage, standing crop biomass, and Shannon-Wiener species diversity index for total species, graminoids, forbs, and tomtza in the western Aru basin ( ${ }^{*}$ indicates $P<0.05$ ).

\begin{tabular}{lrll}
\hline Vegetation characteristic & \multicolumn{1}{c}{$t$} & \multicolumn{1}{c}{$P$} & \multicolumn{1}{c}{$\mathrm{df}$} \\
\hline Total coverage & 1.8753 & 0.07906 & 16.048 \\
Graminoids & 1.2059 & 0.2421 & 19.779 \\
Forbs & -1.0401 & 0.3126 & 17.326 \\
$\quad$ Tomtza & 2.3207 & $0.03742^{*}$ & 12.845 \\
Total standing cro/p & 0.9652 & 0.347 & 18.39 \\
$\quad$ Graminoids & 1.6153 & 0.1239 & 17.762 \\
Forbs & 0.0799 & 0.937 & 20.416 \\
Tomtza & 0.0291 & 0.9772 & 14.338 \\
Shannon index for total & -0.6505 & 0.5225 & 20.727 \\
$\quad$ For graminoids & -1.0472 & 0.3084 & 18.705 \\
For forbs & 1.5116 & 0.1473 & 18.756 \\
\hline
\end{tabular}

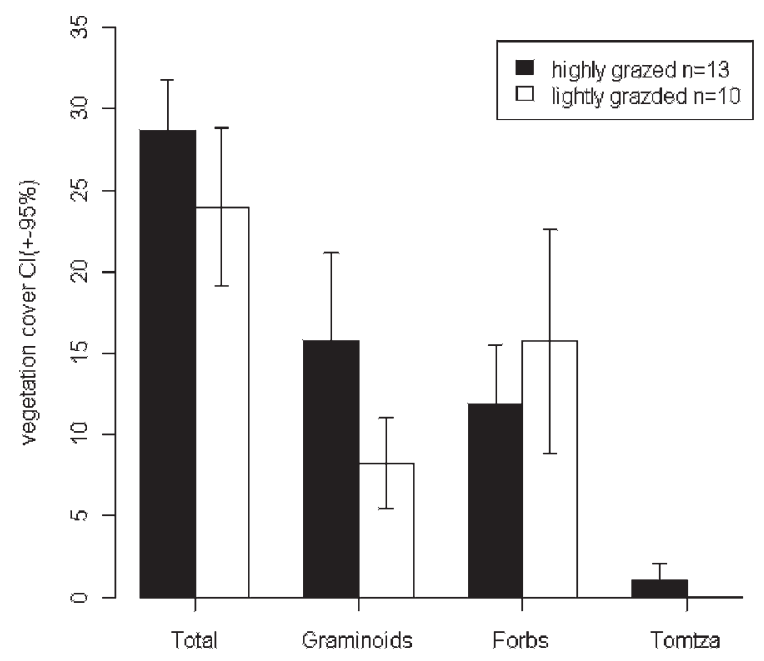

(a)

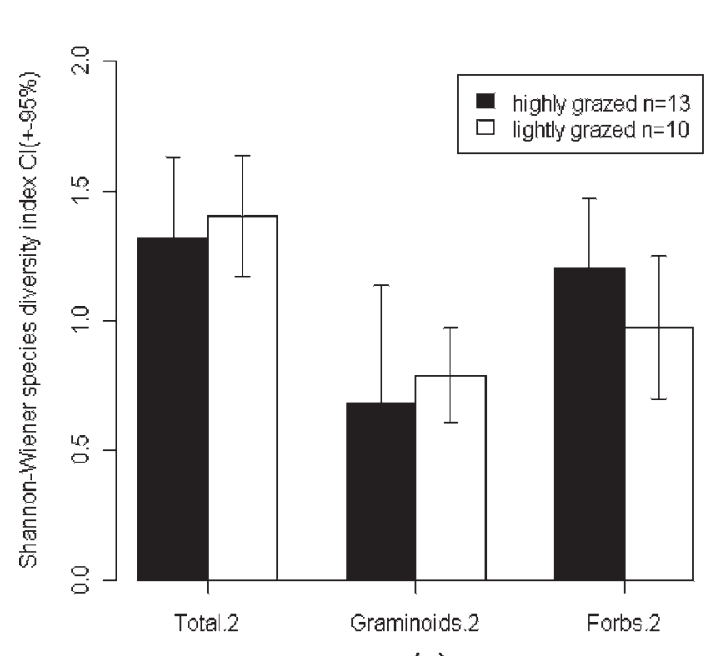

(c) measurement for respective exclosures, which were then used for analyses.

Three soil samples were collected from each sampling area: the low grazed, highly grazed, and within the exclosures, largely for characterizing the sites. These were analyzed for chemical composition, such as available nitrogen $(\mathrm{N})$, available phosphorus $(\mathrm{P})$, available potassium $(\mathrm{K})$, total $\mathrm{N}$, total $\mathrm{P}$, total $\mathrm{K}$, organic matter, and $\mathrm{pH}$. The soil analyses were conducted at the College of Agriculture and Animal Husbandry, Tibet University. Livestock statistics were obtained from local government representatives and household interviews.

\section{Statistical Analyses}

Data sets with a variance much larger than the mean were logtransformed $[\log (\mathrm{x}+1)]$ prior to further analysis (Quinn and Keough 2002) and those with a skewed distribution were transformed by square root [sqrt $(x+0.5)$ ], even if the variance and the mean were about the same. Plants that were not

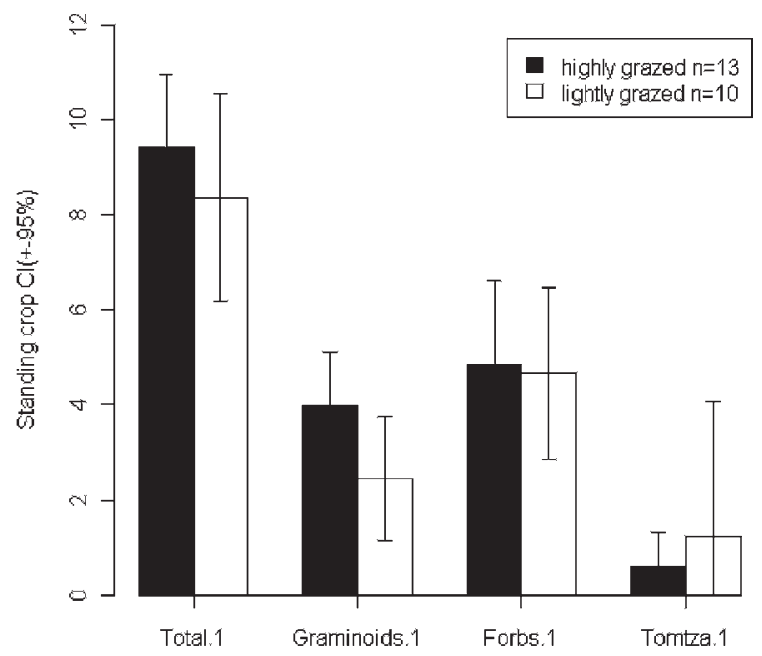

(b)

Figure 3. Bar plots with $95 \%$ confidence intervals (Cl) illustrating differences in a, vegetation cover $(\%)$; $\mathbf{b}$, standing biomass $\left(\mathrm{g} \cdot 0.25 \mathrm{~m}^{-2}\right)$; and $\mathbf{~}$, Shannon-Wiener species diversity index for total species, graminoids, forbs, and tomtza between the heavily and lightly grazed area in the western Aru basin. 
identified at species level were combined at genus level and analyzed together (e.g. Stipa, Poa, and Carex).

Statistical analyses were performed primarily using the statistical package R 2.8.1 (R Development Core Team 2008). Welch's $t$ tests were used to compare the effects of grazing intensity on vegetation cover, productivity (reflect annual productivity), and Shannon-Wiener species diversity index (calculated with species richness and abundance data) for the two functional groups mentioned above (graminoid, forb), tomtza, and sum of all these three groups denoted as "total." Welch's $t$ tests also were used to assess the effects of grazing during the study period (summer 2005), with data obtained from inside and outside exclosures in the highly grazed areas. Detrended correspondence analysis (DCA) with environmental variables fitted post hoc to the ordination space was used to assess the distribution of plant species and their abundance in relation to the different environmental variables. Canonical correspondence analysis (CCA) with Monte Carlo Permutation Test was used to explore the significance of each environmental variable in relation to the species data and to assess what percentage of variation in the data set was explained by each environmental variable. The CCA with partial test was used to examine how much of the variation in the floristic data was explained by environmental variables. Variables with high variance inflation factors were deleted when DCA and CCA were performed to reduce interferences that existed between factors. DCA and CCA were performed and ordination diagrams were made by using two Windows-based programs, Canoco for Windows 4.5 and CanoDraw for Windows (ter Braak and Šmilauer 2002).

\section{RESULTS}

\section{Effects of Grazing on the Highly Grazed Site}

The Welch's $t$ tests results showed that comparisons of vegetation characteristics inside and outside the exclosures in the highly grazed area showed no significant differences (Table 1; Fig. 2). These overall results indicate that the effect of livestock grazing during the summer of 2005 (one season exclosures) was not substantial at the heavily grazed site. However, we still expected that long history of livestock grazing would have had substantial impacts on vegetation characteristics compared to the site that was lightly grazed. Thus, data from both inside and outside the exclosures in the heavily grazed site were combined for further analyses. These combined data then were used to compare with those from the lightly grazed area to assess differences in vegetation measurements that present long-term differences in livestock grazing intensities.

\section{Effects of Long-term Grazing Intensity in Western Aru Basin}

The Welch's $t$ tests on vegetation characteristics along the transects associated with grazing intensity showed no significant differences, except for one variable, tomtza cover, which was significantly higher in the heavily grazed site (Table 2; Fig. 3). Such results indicate that the grazing has not had a significant impact on plant cover, standing crop biomass, and Shannon-Wiener species diversity index in general, thus implying that plant-herbivore interactions might not be an

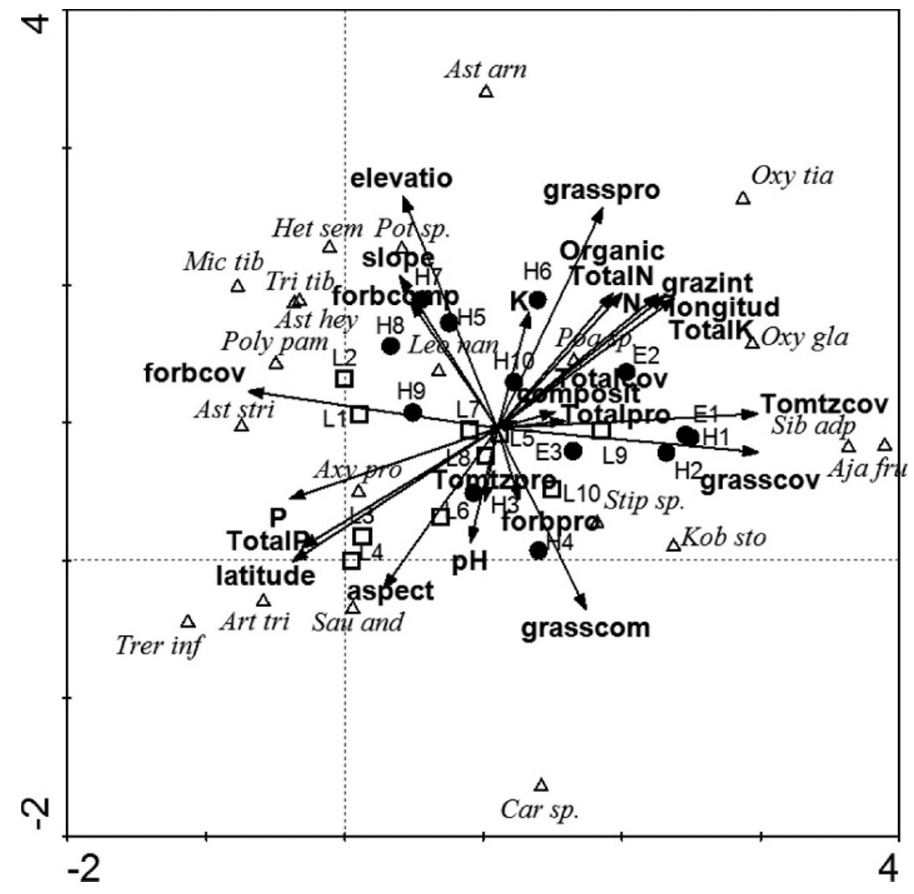

Figure 4. Ordination plot for species, sample units (transects), and environmental variables for Detrended Correspondence Analysis. Black dots represent samples derived from the heavily grazed area and the squares represent samples taken from the lightly grazed site. The arrows represent explanatory variables: grazint indicates grazing intensity; Totalcov, total coverage; grasscov, graminoid coverage; forbcov, forb coverage; Tomtzcov, tomtza coverage; Totalpro, total standing biomass; grasspro, graminoid standing biomass; forbpro, forb standing biomass; Tomtzpro, tomtza standing biomass; composit, total species richness; grasscom, graminoid species richness; forbcomp, forb species richness; $\mathrm{N}$, available nitrogen; $\mathrm{P}$, available phosphorus; $\mathrm{K}$, available potassium; TotalN, total nitrogen; TotalP, total phosphorus; and TotalK, total potassium.

overriding factor influencing vegetation parameters even in western Aru basin, one of the least arid sites of the western Chang Tang.

The DCA with environmental variables showed that grazing intensity was not highly correlated with either axis 1 or 2 (Fig. 4), thus indicating that grazing intensity might not be the most important variable in explaining variation in floristic data. This result is consistent with nonequilibrium ecosystem dynamics. However, Figure 4 shows that plant species unpalatable to livestock, such as O. glacialis and Oxytropis tianschanica Bunge, were more associated with the heavily grazed site, whereas palatable forage species, including Thermopsis inflata Cambess., Artemisia tridactyla Hand.Mazz., and Saussurea andryaloides (DC.) Sch. Bip. were associated with the lightly grazed site.

After introducing the interactions between environmental variables into the analyses (conditional effects), the CCA with Monte Carlo Permutation test also indicated that grazing intensity did not explain a significant amount of variation in the plant species data (Table 3). Soil chemical components apparently played a minor role in explaining the vegetation characteristics tested, and of the topographic features, only elevation contributed significantly (Table 3). 
Table 3. Monte Carlo Permutation test ${ }^{1}$ results for conditional effects of environmental variables.

\begin{tabular}{|c|c|c|c|c|c|}
\hline Variable & $N$ & Lambda & $\mathrm{F}$ ratio & $P$ value & Percent variance explained (\%) \\
\hline Forb coverage & 23 & 0.27 & 4.08 & 0.002 & 0.27 \\
\hline Tomtza coverage & 22 & 0.22 & 3.61 & 0.002 & 0.22 \\
\hline Elevation & 18 & 0.21 & 4.00 & 0.002 & 0.21 \\
\hline Forb species richness & 25 & 0.12 & 2.40 & 0.008 & 0.12 \\
\hline Total species richness & 7 & 0.11 & 2.38 & 0.006 & 0.1 \\
\hline Graminoid species richness & 24 & 0.07 & 1.56 & 0.098 & 0.07 \\
\hline Graminoid standing biomass & 4 & 0.07 & 1.66 & 0.09 & 0.07 \\
\hline Slope & 17 & 0.05 & 1.32 & 0.19 & 0.05 \\
\hline Graminoid coverage & 21 & 0.04 & 1.02 & 0.446 & 0.05 \\
\hline Grazing intensity & 2 & 0.06 & 1.5 & 0.114 & 0.06 \\
\hline Total coverage & 1 & 0.04 & 1.01 & 0.425 & 0.04 \\
\hline Tomtza standing biomass & 6 & 0.03 & 0.83 & 0.532 & 0.03 \\
\hline Total standing biomass & 3 & 0.03 & 0.71 & 0.676 & 0.03 \\
\hline Forb standing biomass & 5 & 0.04 & 1.01 & 0.456 & 0.04 \\
\hline Aspect & 16 & 0.05 & 1.23 & 0.265 & 0.05 \\
\hline Latitude & 19 & 0.03 & 0.77 & 0.594 & 0.03 \\
\hline $\mathrm{pH}$ & 8 & 0.03 & 0.8 & 0.548 & 0.03 \\
\hline N (available nitrogen) & 9 & 0.03 & & & \\
\hline K (available potassium) & 10 & 0.03 & & & \\
\hline P (available phosphorus) & 11 & 0.03 & & & \\
\hline Organic & 12 & 0.03 & & & \\
\hline Total N & 13 & 0.03 & & & \\
\hline Total P & 14 & 0.03 & & & \\
\hline Total K & 15 & 0.03 & & & \\
\hline All environmental variables together & & & & & 1.47 \\
\hline
\end{tabular}

${ }^{1} \mathrm{~A}$ total of 490 permutation tests were performed by setting options in Canonical Correspondence Analysis using Canoco for Windows 4.5 .

The CCA with partial test (Table 4) further indicated that topographic features and soil chemical components explained only $9 \%$ and $2 \%$, respectively, of the total variation in species data when interactions between environmental variables were taken into account in the analyses. Grazing intensity explained virtually none of the floristic variation (Table 4). Nevertheless, $36 \%$ of total variation in the floristic data, based on the sum of the canonical eigenvalues expressed as percentages of the total variance of the species data, was explained by the combined effects of all the environmental variables interacting with each other (Table 4).

Table 4. Partial Canonical Correspondence Analysis test result for quantifying the shared and unique components of variation explained by the different categories of environmental variables: A) the main hypothetical factor (grazing intensity); B) vegetation attributes (total coverage, grass coverage, forb coverage, tomtza coverage, total productivity, graminoid productivity, forb productivity, tomtza productivity, total species richness, graminoid species richness, forb species richness); C) soil chemical components (nitrogen [N], phosphorous [P], potassium [K], total N, total P, total K, organic material, and pH); D) topographic features (aspect, slope, elevation, latitude, and longitude).

\begin{tabular}{|c|c|c|}
\hline Source & Sum of all canonical Eigenvalues & Percent of variance explained \\
\hline A as the only environmental variable & 0.193 & 11.4269 \\
\hline $\mathrm{B}$ as the only environmental variable & 1.19 & 70.4559 \\
\hline $\mathrm{C}$ as the only environmental variable & 0.279 & 16.2226 \\
\hline D as the only environmental variable & 0.781 & 46.2404 \\
\hline All the environmental variables together & 1.474 & 87.2706 \\
\hline A pure ( $A$ as environmental variable, $B+C+D$ as covariable) & 0 & 0 \\
\hline$B$ pure ( $B$ as environmental variable, $A+C+D$ as covariable) & 0.673 & 39.8461 \\
\hline$C$ pure ( $C$ as environmental variable, $A+B+D$ as covariable) & 0.034 & 2.013 \\
\hline$D$ pure ( $D$ as environmental variable, $A+B+C$ as covariable) & 0.156 & 9.2362 \\
\hline \multicolumn{3}{|c|}{$A, B, C$, and $D$ shared explanation all the environmental variables together $(A$ pure $+B$ pure $+C$} \\
\hline pure $+D$ pure) & 0.611 & 36.1753 \\
\hline Unexplained & 0.215 & 12.7294 \\
\hline Total Variance & 1.689 & 100 \\
\hline
\end{tabular}

\footnotetext{
${ }^{1}$ Percent variance explained is the sum of the canonical eigenvalues expressed as percentages of the total variance of the species data.
} 


\section{DISCUSSION}

With no significant differences in most vegetation parameters between heavily and lightly grazed sites, these results indicate a domination of nonequilibrium dynamics in the western Aru basin, similar to low-precipitation rangeland ecosystems elsewhere (Milchunas et al. 1988; Cingolani et al. 2005). However, the significantly higher cover of the poisonous plant tomtza in the heavily grazed site suggests a characteristic of equilibrium ecosystems where high-intensity grazing can reduce the competitiveness of dominant palatable plants (van der Maarel 2005). Nevetheless, the low cover of tomtza $(1.04 \%$ at the heavily grazed site vs. $0.02 \%$ at the lightly grazed site) diminishes the importance of this effect, and any conclusions of continuum of equilibrium and nonequilibrium dynamics require further study.

We acknowledge that given the limited sample size and the lack of multiannual observations of this study, it is not yet possible to definitively describe the ecosystem dynamics of this region, because annual and seasonal variation in precipitation can impact vegetation in ways that further influence these dynamics (Connell and Sousa 1983; DeAngelis and Waterhouse 1987; Illius and O'Connor 1999). However, because the study area has been consistently grazed by livestock as summer pasture for at least 15 consecutive yr, and as a major autumnwinter congregation area for Tibetan antelope (Schaller 1998; Fox et al. 2004), the impact of such long-term grazing would likely be manifest on vegetation parameters if the system operated in an equilibrium manner (Wahren et al. 1994).

\section{IMPLICATIONS}

Current policies instituted in the Aru basin are based on the assumption of a constant carrying capacity with resultant set stocking rates, allocation of rangeland parcels to each individual household, and initial fencing of herding group boundaries (Fox et al. 2009). The efficacy of such policies for the efficient utilization of China's western rangelands already has been questioned from a livestock production point of view (Yan et al. 2005), but they are even more suspect when considering areas with major wildlife conservation goals that include wild herbivores, such as is seen in the Aru basin (Fox et al. 2009). Conflicts already have surfaced, because local nomads now are avoiding areas showing increases in the poisonous plant tomtza, and therefore are expanding their grazing pastures into areas of wildlife importance. As a result, wildlife could lose important habitat and potentially decrease in the future, if a realistic management strategy is not created to accommodate both animal husbandry and wildlife conservation (Fox et al. 2009). If domination of nonequilibrium dynamics is actually the case throughout the western Chang Tang region, carrying capacity would be too variable to be represented by a constant stocking rate. More opportunistic strategies are required for management of livestock, while recognizing the production limits of the system and the needs of wild grazers in the nature reserve. Management of wildlife and livestock within the Chang Tang Nature Reserve will be a daunting task; a recognition and understanding of ecosystem dynamics in the application of appropriate management regimes is critical to the success of both animal husbandry and wildlife conservation goals.

\section{ACKNOWLEDGMENTS}

We extend special thanks to Ms Drolma Yangzom at the Tibet Autonomous Region Forestry Bureau for her and her agency's support of this work in the nature reserve. Plant species identifications used here were provided by Drs B. Dickoré, G. Miehe, and S. Miehe from the University of Marburg, Germany, and were based on a combination of plant specimens and photographs. We also extend our acknowledgment to the two anonymous reviewers for their valuable comments. Thanks to $\mathrm{Mr}$ Andres Ordiz Fernandez for helping us translate the English abstract into Spanish.

\section{LITERATURE CITED}

Behnke, R., and I. Scoones. 1993. Rethinking range ecology, implications for rangeland management in Africa. In: R. Behnke, I. Scoones, and C. Kerven [EDS.]. Range ecology at disequilibrium: new models of natural variability and pastoral adaptation in African savannas. London, United Kingdom: IIED/ODI/ Commonwealth Secretariat. p. 1-30.

Briske, D. D., S. D. Fuhlendorf, and F. E. Smeins. 2003. Vegetation dynamics on rangelands, a critique of the current paradigms. Journal of Applied Ecology 40:601-614.

Cingolani, A. M., I. Noy-MeiR, and S. Diaz. 2005. Grazing effects on rangeland diversity: a synthesis of contemporary models. Ecological Applications 15:757-773.

ConneLL, J. H., AND W. P. SousA. 1983. On the evidence needed to judge ecological stability or persistence. American Naturalist 121:789-824.

Deangelis, D. L., and J. C. Waterhouse. 1987. Equilibrium and nonequilibrium concepts in ecological models. Ecological Monographs 57:1-21.

ELLIS, J. E. 1995. Climate variability and complex ecosystem dynamics: implication for pastoral development. In: I. Scoones [ED.]. Living with uncertainty: new directions in pastoral development in Africa. London, United Kingdom: Intermediate Technology Publication. p. 37-46.

Fernandez-Gimenez, M. E., and B. Allen-Diaz. 1999. Testing a non-equilibrium model of rangeland vegetation dynamics in Mongolia. Journal of Applied Ecology 36:871-885.

Fisser, H. G., and G. M. Van Dyne. 1966. Influence of number and spacing of points on accuracy and precision of basal cover estimates. Journal of Range Management 19:205-211.

Fox, J. L., K. Dhondup, and T. DoRJ. 2009. Tibetan antelope Pantholops hodgsonii conservation and new rangeland management policies in the Chang Tang Nature Reserve, Tibet: is fencing creating an impasse? Oryx 43:183-190.

Fox, J. L., P. Mathiesen, D. Yangzom, M. W. Næss, and B. Xu. 2004. Modern wildlife conservation initiatives and the pastoralist/hunter nomads of northwestern Tibet. Rangifer, Special Issue 15:17-27.

Fox, J. L., C. Yangzong, K. Dondhup, And T. Dorul. 2008. Biodiversity conservation and pastoralism on the northwest Tibetan Plateau (Byang thang): coexistence or conflict? Journal of the International Association of Tibetan Studies 4:1-21.

GILlson, L., AND M. T. HOFFmAn. 2007. Rangeland ecology in a changing world. Science 315:53-54.

Heikinen, R. K., H. J. B. Birks, and R. J. Kalliola. 1998. A numerical analysis of the mesoscale distribution patterns of vascular plants in the subarctic Kevo nature reserve, Northern Finland. Journal of Biogeography 25:123-136.

Illius, A. W., AND T. G. O'Connor. 1999. On the relevance of nonequilibrium concepts to arid and semiarid grazing system. Ecological Applications 9:798-813.

Jackson, R. B., and M. M. Caldwell. 1993. Geostatistical patterns of soil heterogeneity around individual perennial plants. Journal of Ecology 81:683-692.

KörneR, C. 2003. Alpine plant life, functional plant ecology of high mountain ecosystems. Berlin, Germany: Springer-Verlag. 344 p. 
LIU, W. 1999. Chang Tang: a high and holy realm in the world. Beijing, China: Chinese Forestry Publishing House. $186 \mathrm{p}$.

Milchunas, D., O. Sala, and W. Lauenroth. 1988. A generalized model of the effects of grazing by large herbivores on grassland community structure. American Naturalist 132:87.

PICKUP, G., AND G. N. BAstin. 1997. Spatial distribution of cattle in arid rangelands as detected by patterns of change in vegetation cover. Journal of Applied Ecology 34:657-667.

Pickup, G., G. N. Bastin, and V. H. Chewings. 1998. Identifying trends in land degradation in non-equilibrium rangelands. Journal of Applied Ecology 35:365-377.

Quinn, G. P., and M. L. KeOUgh. 2002. Experimental design and data analysis for biologists. Cambridge, United Kingdom: Cambridge University Press. 537 p.

R Development Core Team. 2008. R: a language and environment for statistical computing. Vienna, Austria: R Foundation for Statistical Computing. Available at: http://www.R-project.org. Accessed 22 December 2008.

Rahel, F. J., J. D. Lyons, and P. A. Cochran. 1984. Stochastic or deterministic regulation of assemblage structure? It may depend on how the assemblage is defined. American Naturalist 124:583-589.

Rorison, I. H., F. SUtTon, AND R. Hunt. 1986. Local climate, topography and plant growth in Lathkill Dale NNR. I. A twelve-year summary of solar radiation and temperature. Plant, Cell, and Environment 9:49-56.

SchalleR, G. B. 1998. Wildlife of the Tibetan steppe. Chicago, IL, USA: University of Chicago Press. 373 p.

SCOONES, I. 1995. Living with uncertainty: new directions in pastoral development in Africa. London, United Kingdom: Intermediate Technology Publications. $208 \mathrm{p}$.
Semenova, G. V., and E. van der Maarel. 2000. Plant functional types: a strategic perspective. Journal of Vegetation Science 11:917-922.

Shinneman, D. J., AND W. L. Baker. 1997. Nonequilibrium dynamic between catastrophic disturbances and old-growth forests in ponderosa pine landscape of the Black Hills. Conservation Biology 11:1276-1288.

TAN, Y. Y., J. H. Wang, Q. F. LI, G. Q. LI, Z. L. Hong, J. X. GAO, and Q. H. Guo. 2002. Identification of the alkaloid isolated from glacial crazyweed (Oxytropis glacialis Benth ex Bye) in Ali Prefecture in Xi Zang (Tibet). Chinese Journal of Veterinary Science 21:595-596. (In Chinese).

ter Braak, C. J. F., and P. Šmilauer. 2002. Canoco 4.5 reference manual and canoDraw for windows user's guide: software for canonical community ordination (version 4.5). Ithaca, NY, USA: Microcomputer Power. 500 p.

Theodose, T., AND W. Bowman. 1997. Nutrient availability, plant abundance, and species diversity in two alpine tundra communities. Ecology 78:1861-1872.

ValentinE, K. A. 1945. Distance from water as a factor in grazing capacity of rangeland. Journal of Forestry 45:749-754.

van der Maarel, E. 2005. Vegetation ecology—an overview. In: E. van der Maarel [ED.]. Vegetation ecology. Oxford, United Kingdom: Blackwell Science. p. 1-52.

Wahren, C., W. Papst, and R. Williams. 1994. Long-term vegetation change in relation to cattle grazing in subalpine grassland and heathland on the Bogong High Plains: an analysis of vegetation records from 1945 to 1994. Australian Journal of Botany 42:607-640.

WarReN, A. 1995. Changing understandings of African pastoralism and the nature of environmental paradigms. Transactions of the Institute of British Geographers 20:193-203.

YAN, Z., N. Wu, D. YESHI, AND J. Ru. 2005. A review of rangeland privatization and its implications in the Tibetan plateau, China. Nomadic Peoples 21:31-51. 